\title{
EFFECTS OF GROWING LOCATION AND COLD STORAGE ON NUTRITIONAL VALUES OF PURPLE CARROT (DAUCUS CAROTA SSP. SATIVUS VAR. ATRORUBENS ALEF) GENOTYPES
}

\author{
CEBECI, E. ${ }^{*}{ }^{*}-$ HANCI, F. ${ }^{2}$ \\ ${ }^{I}$ Bati Akdeniz Agricultural Research Institute, Muratpasa, Antalya, Turkey \\ ${ }^{2}$ Department of Horticulture, Faculty of Agriculture, Erciyes University, Kayseri, Turkey \\ *Corresponding author \\ e-mail:esrac3@hotmail.com; phone:+90-532-583-3701
}

(Received $4^{\text {th }}$ Jul 2019; accepted $16^{\text {th }}$ Oct 2019)

\begin{abstract}
Purple carrots (Daucus carota ssp. Sativus var. Atrorubens Alef) have received much attention as a natural source of antioxidants, which is confirmed to reduce risk of cancer when consumed frequently. In this study, six purple carrot genotypes (DC17, DC28, DC33, DC34, DC36, and DC37) collected from Anatolia, produced under two distant and very different ecological conditions. Field trials have been planned according to the randomized complete blocks design with three replications. After the harvest, antioxidant activity, total phenolic, total flavonoid, anthocyanin, total soluble solid, titratable acidity and invert sugar values of stored and non-stored roots were assessed. Anthocyanin, total flavonoid and total phenolic content of the six genotypes ranked between 11.3-1,692.4 mg/l. 412.7-3,242.4 mg $\mathrm{KE} / 100 \mathrm{~g}$ and $491.4-5,772.3 \mathrm{mg}$ GAE$/ 100 \mathrm{~g}$ respectively. Antioxidant activity was determined to be between 9,848.46-3,274.62 $\mu \mathrm{mol}$ TE $100 \mathrm{~g}^{-1}, 4,676.9-235.6 \mu \mathrm{mol}$ TE $100 \mathrm{~g}^{-1}$ according to 1.1-diphenyl-2picrylhydrazyl (DPPH) and ferric reducing ability of plasma (FRAP) assays respectively. According to the results, the studied parameters of the genotypes were significantly affected. Different ecological conditions affected the phytochemical composition of the purple carrot roots. The effect of storage on all parameters except total flavonoid content was found significant.
\end{abstract}

Keywords: anthocyanin, antioxidant activity, flavonoids, phenolic, titratable acidity

\section{Introduction}

Carrot (Daucus carota L.) is a biennial, cool-season vegetable, belonging to Apiaceae family. In terms of both production areas and market value, it is amongst the top-ten most important vegetable crop in the world (Simon et al., 2008). Cultivated carrot is divided into two main varieties; the western carrot with orange, yellow or white roots and the oriental carrot with black, purple, red or rarely yellowish roots (Esatbeyoglu et al., 2016).

Production of orange carrot has increased initially in large areas and this led to the gradual disappearance of the other colored varieties, today a new trend is being noticed which is named conservation of biodiversity. In addition to this, improved understanding of the importance of healthy nutrition in human dietary and preventive medicine increased the consumption of vitamin-rich vegetables such as carrot. Obviously, different colors are caused by different chemical compositions namely anthocyanin in purple or black ones (Arscott and Tanumihardjo, 2010). Nowadays, consumption of black or purple carrots is increasing steadily due to their definition as an important source of natural antioxidants (Sharma et al., 2012). Purple or black carrot is useful source of minerals and vitamins and it contains high amount of anthocyanin, which is known as natural dye used in the food industry. Because of their healthful 
properties, the development of food colorants from the natural sources has increased interest as alternatives to synthetic dyes (Smeriglio et al., 2018).

Additionally, purple carrot roots have 9 times more phenolic than roots of other colored carrots also they have high antiradical activity which is caused from high anthocyanin content (Leja et al., 2013). As well as the availability of common antioxidants such as vitamins $\mathrm{C}$ and $\mathrm{E}$, purple carrots have much more interest with their phenolic (Alasalvar et al., 2001; Kirca et al., 2006; Singh et al., 2011), which contributed to the antioxidant capacity positively (Algarra et al., 2014). In particular, purple carrots have higher antioxidant capacity in comparison with other colors (Sun et al., 2009). Nicolle et al. (2004) tried to understand the influences of genetic variability on carotenoid, vitamin, phenolic and mineral content of the different carrot roots to assist the breeding programs. Purple carrots are often consumed processed (Alasalvar et al., 2001). Limited fresh consumption of them has been maintained in Turkey for years. Mostly it has been used to produce of local drink called 'salgam'. In recent years, production has been increasing dramatically due to the use for anthocyanin extraction by the pigment industry; more than $90 \%$ of the purple carrots produced in Turkey are being used by this industry (Ipek et al., 2016).

Because of favorable climate and soil conditions, purple carrot production is mostly spread in Turkey's Konya province. It is considered that quality of the purple carrot roots harvested from this area higher than the other production areas. This makes Konya's purple carrot locally called "Black Carrot" to be well known by the world and makes it an important export product. In this study, the effects of different ecologies on root quality were compared. It is thought that at the end of the project, obtained results could be contributed to spread the production out of the certain growth areas thus; production of purple carrot, also consumption of the vegetable with obvious benefits could be increased. Purple carrot roots, generally consumed by processing, before fabricated they may have to be stored for several months. During the storage, some visible deteriorations occur in the carrot roots and the effects of storage on root quality are not clear. With this study the effects of storage on the quality of the purple carrot roots was determined. Briefly, this study aims to compare the effects of different ecological conditions and long-term cooled storage on the quality characteristics of six local purple carrot genotypes. In this research "quality characteristics" means, determination of antioxidant activity (AA), contents of anthocyanin (AC), total phenolic (TP), total flavonoids (TF), titratable acidity (TA), total soluble solids (TSS), invert sugar (IS) values of the purple carrot root samples.

\section{Materials and methods}

\section{Plant material}

In the current study, six black carrot genotypes (DC17, DC28, DC33, DC34, DC36, and DC37) collected from the general production areas of Konya province were used as a plant material. These genotypes have been maintained in a limited area (nearly 20 000 da in Eregli and Karapınar regions) by local farmers who act as a seed saver for many years. Before this study, root samples were collected by visits to the local carrot growing fields in Kuzukuyu, Pınarozu, Akoren villages and Basin plateau in Ereğli District within another project. Collected roots brought to the institutes which are located in Yalova $\left(40^{\circ} 39^{\prime} \mathrm{N}, 29^{\circ} 17^{\prime} \mathrm{E}\right)$ and Konya (Karapinar region; $37^{\circ} 42^{\prime} \mathrm{N}, 33^{\circ}$ $33^{\prime}$ E) for planting and selfing. Selfed purple carrot seeds were planted separately when 
the season was appropriate. After a successful vegetation period harvested root samples were divided in two parts and non-stored roots were directly taken to the laboratory. The other part was stored for two months in the cold storage, temperature ranged from 2 to $3{ }^{\circ} \mathrm{C}$ and relative humidity (RH) was 85 to $90 \%$. Followed to the storing stage, these samples were taken to the laboratory likewise. Extraction and the laboratory analyzes were done three times at the Ataturk Central Horticultural Research Institute, Yalova.

\section{Field trials}

Field trials planned according to the randomized complete blocks design with three replications. Each trial areas' soil conditions are listed in Table 1. Because of the climatic conditions (Table 2) seed sowing was done on May 15 in Konya and on August 15 in Yalova, harvest was started November 15 in Konya and February 15 in Yalova between the years of 2016-2017.

Table 1. Pedological properties of the tested soils

\begin{tabular}{c|c|c|c|c|c|c|c|c}
\hline Location & $\begin{array}{c}\text { WHC } \\
(\boldsymbol{\%})\end{array}$ & $\mathbf{p H}$ & $\begin{array}{c}\mathbf{O M} \\
(\boldsymbol{\%})\end{array}$ & $\begin{array}{c}\mathbf{C a C O}_{3} \\
(\boldsymbol{\%})\end{array}$ & $\begin{array}{c}\mathbf{P}_{2} \mathbf{O}_{\mathbf{5}} \\
\mathbf{m g ~ k g}^{-1}\end{array}$ & $\begin{array}{c}\mathbf{K}_{\mathbf{2}} \mathbf{O} \\
\left(\mathbf{m e 1 0 0 g ^ { - 1 }}\right)\end{array}$ & $\begin{array}{c}\mathbf{E C} \\
\left(\mathbf{m m h o s ~ c m}^{-\mathbf{1}}\right)\end{array}$ & Class \\
\hline Konya & 37.40 & 8.39 & 0.99 & 56.11 & 9.64 & 103.33 & 220 & Loamy \\
Yalova & 68.00 & 7.68 & 2.09 & 0.60 & 5.70 & 0.53 & 191 & Clay loam \\
\hline
\end{tabular}

WHC: water holding capacity, OM: organic matter

Table 2. Weather conditions of Yalova and Konya province during 2016 (Anonymous, 2018)

\begin{tabular}{|c|c|c|c|c|c|c|c|c|c|c|}
\hline \multirow{3}{*}{ Months } & \multicolumn{6}{|c|}{ Temperature $\left({ }^{\circ} \mathbf{C}\right)$} & \multirow{2}{*}{\multicolumn{2}{|c|}{$\begin{array}{c}\text { Average humidity } \\
(\%)\end{array}$}} & \multirow{2}{*}{\multicolumn{2}{|c|}{$\begin{array}{l}\text { Total rainfall } \\
\quad(\mathbf{m m})\end{array}$}} \\
\hline & \multicolumn{2}{|c|}{ Minimum } & \multicolumn{2}{|c|}{ Maximum } & \multicolumn{2}{|c|}{ Average } & & & & \\
\hline & Yalova & Konya & Yalova & Konya & Yalova & Konya & Yalova & Konya & Yalova & Konya \\
\hline Jan. & 4.5 & -4.6 & 10.2 & 5.5 & 6.9 & 0.0 & 73.5 & 75.4 & 136.4 & 40.8 \\
\hline Feb. & 8.1 & -0.2 & 14.8 & 13.8 & 11.0 & 6.5 & 76.3 & 65.1 & 74.4 & 7.2 \\
\hline Mar. & 7.6 & 0.2 & 15.0 & 15.5 & 10.9 & 7.7 & 73.2 & 54.7 & 91.9 & 34.4 \\
\hline Apr. & 11.2 & 4.9 & 21.3 & 22.9 & 15.7 & 14.2 & 69.1 & 42.1 & 32.2 & 4.8 \\
\hline May & 14.0 & 8.8 & 29.0 & 23.8 & 18.1 & 16.0 & 73.4 & 55.6 & 56.1 & 44.4 \\
\hline June & 18.3 & 13.8 & 22.9 & 29.4 & 23.4 & 21.8 & 69.3 & 44.7 & 29.4 & 33.8 \\
\hline July & 19.9 & 14.8 & 30.8 & 31.8 & 25.0 & 24.0 & 70.3 & 36.7 & 4.6 & 0.0 \\
\hline Aug. & 25.6 & 15.5 & 30.3 & 32.9 & 25.4 & 24.4 & 76.2 & 38.5 & 52.9 & 20.2 \\
\hline Sept. & 16.8 & 8.9 & 26.3 & 25.8 & 21.1 & 17.5 & 73.4 & 48.3 & 39.6 & 24.4 \\
\hline Oct. & 12.5 & 4.4 & 20.0 & 22.1 & 15.9 & 13.1 & 78.9 & 48.5 & 34.1 & 0.6 \\
\hline Nov. & 8.8 & -3.3 & 15.8 & 14.3 & 11.9 & 5.0 & 75.3 & 57.4 & 97.7 & 10.2 \\
\hline Dec. & 2.8 & -8.1 & 7.6 & 2.3 & 4.9 & -2.3 & 80.7 & 82.6 & 153.4 & 97.8 \\
\hline
\end{tabular}

\section{Physicochemical analysis}

After sowing, cultural practices have been done properly throughout the season in two trial areas. Following the harvest, AA, TP, TF, AC, TSS, TA, and IS values of stored and non-stored roots were investigated in 2017. The amount of TF in extracts was determined spectrophotometrically according to the Folin-Ciocalteu method (Thaipong et al., 2006). Total flavonoid content of extracts was measured according to 
the modified method of Zhisnen et al. (1999). Anthocyanin quantitation was performed by the $\mathrm{pH}$ differential method (Moyer et al., 2002). Antioxidant activity was determined by two methods which were 1,1-diphenyl-2-picrylhydrazyl (DPPH) (Thaipong et al., 2006) and ferric reducing ability of plasma (FRAP) (Benzie and Strain, 1996) because of no single method represents AA well. TSS values, were determined by the Abbe refractometer, TA and IS values determined according to Cemeroglu (2007).

\section{Statistical analysis}

Study was completed between the years of 2015-2017. Field trials planned according to the randomized complete blocks design with three replications and laboratory tests were done 3 times. All data were analysed using analysis of variance (ANOVA). Analysis of variance was employed to compare the means of genotypes, location, storage and their interactions. The significance of differences between results was determined by DUNCAN multiple comparison technique. The statistical significance is indicated within the Table $3(\mathrm{p}<1 \%)$.

\section{Results and discussion}

Trial areas' soil conditions are listed in Table 1. According to the analyzes, Konya's soil is loamy and poor in organic matter, Yalova's soil is clay-loam and richer in organic matter compared to the Konya. According to Table 2, climatic conditions of the trial sites are quite different from each other, such as while Yalova was temperate and rainy Konya was arid and hot throughout the growing period. Because of this, different periods of the year were selected for root production. After the harvest it was observed that, the differences between the areas weather and soil conditions affect the roots visible quality, which means harvested roots from Konya looked smoother and marketable compared to the Yalova's mostly shapeless and rough roots. It is thought that, Yalova's different day and night temperature regimes and high air and soil humidity could lead to, undesired lateral root branching and woody root growth. In addition to this it was understood from the researchers' previous studies that, production of purple carrot during spring and summer time cause the undesired early flowering in Yalova conditions. Therefore, cultivation was started in late August for Yalova. Seljasen et al. (2013) reported that quality characteristics of carrots are very sensitive to the influences of biotic and abiotic stresses.

The results of variance analyses for the investigated characters were showed in Table 3. All characters were significant for the interaction of three factors (genotype, location and storage) except TF content and TA values $(\mathrm{P}<0.01)$. The content of TF and TA were significant for interaction of genotype $\times$ storage, and genotype $\times$ location (Table 3).

According to variance analysis, there was not individual effect of each factor on the content of IS, so all the results about IS, TSS, AC, TP, FRAP and DPPH were compared to each other (totally 24 values) and all the results were summarized in Table 4. The lowest IS content measured in genotype-DC28 harvested from Yalova

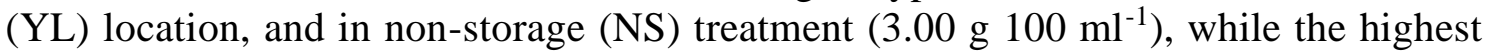
value obtained from genotype-DC33 harvested from same location and storage (S) treatment (69.25 g $\left.100 \mathrm{ml}^{-1}\right)$. In a study conducted by Ersus and Yurdagel (2007) IS

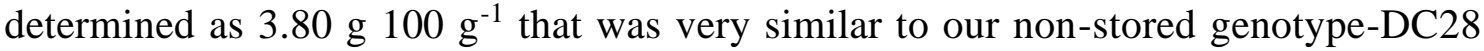
harvested from Yalova. 
Table 3. The results of variance analysis

\begin{tabular}{c|c|c|c|c|c|c|c|c|c}
\hline & \multirow{2}{*}{$\begin{array}{c}\text { C. } \\
\text { Total }\end{array}$} & \multirow{2}{*}{ Error } & Genotype & Location & Storage & $\begin{array}{c}\text { Genotype } \\
\times \text { location }\end{array}$ & $\begin{array}{c}\text { Genotype } \times \\
\text { storage }\end{array}$ & $\begin{array}{c}\text { Location } \\
\times \text { storage }\end{array}$ & $\begin{array}{c}\text { Genotype } \times \\
\text { location } \times \\
\text { storage }\end{array}$ \\
\hline DF & 71 & 48 & 5 & 1 & 1 & 5 & 5 & 1 & 5 \\
DPPH & & & $610.19^{*}$ & $30.41^{*}$ & $10.64^{*}$ & $147.54^{*}$ & $42.94^{*}$ & $1.28^{\mathrm{ns}}$ & $29.8^{*}$ \\
FRAP & & & $130.25^{*}$ & $66.46^{*}$ & $1.48^{\mathrm{ns}}$ & $74.54^{*}$ & $199.22^{*}$ & $21.89^{*}$ & $60.98^{*}$ \\
TP & & & $1,087.28^{*}$ & $0.01^{\mathrm{ns}}$ & $7.91^{*}$ & $24.33^{*}$ & $21.21^{*}$ & $2.12^{\mathrm{ns}}$ & $16.71^{*}$ \\
TF & & & $178.89^{*}$ & $1.67^{\mathrm{ns}}$ & $0.88^{\mathrm{ns}}$ & $2.46^{*}$ & $6.72^{*}$ & $0.03^{\mathrm{ns}}$ & $2.27^{\mathrm{ns}}$ \\
AC & & $461.11^{*}$ & $60.04^{*}$ & $5.06^{*}$ & $17.85^{*}$ & $5.02^{*}$ & $2.49^{\mathrm{ns}}$ & $9.59^{*}$ \\
TSS & & & $2,117.25^{*}$ & $7,007.11^{*}$ & $6.53^{*}$ & $892.96^{*}$ & $762.54^{*}$ & $549.16^{*}$ & $339.22^{*}$ \\
TA & & $152.04^{*}$ & $344.10^{*}$ & $660.01^{*}$ & $14.03^{*}$ & $161.18^{*}$ & $0.05^{\mathrm{ns}}$ & $0.05^{\mathrm{ns}}$ \\
IS & & & $439.11^{*}$ & $196.16^{*}$ & $1,946.74^{*}$ & $130.32^{*}$ & $105.77^{*}$ & $4.51^{*}$ & $27.26^{*}$ \\
\hline
\end{tabular}

*Significant ( $\mathrm{p}<0.01)$, ns: non significant F: freedom, DF: degree of freedom, C. Total: corrected total, Dpph: 1,1diphenyl-2-picrylhydrazyl, frap: ferric reducing ability of plasma, TP: total phenol, TF: total flavonoid, AC: antocyanin, TSS: total soluble solids, TA: titratable acidity, IS: invert sugar

Table 4. The effects of storage and location on some parameters of purple carrot genotypes

\begin{tabular}{|c|c|c|c|c|c|c|c|c|}
\hline Tre. & Location & Genotype & IS & TSS & $\mathbf{A C}$ & TP & FRAP & DPPH \\
\hline \multirow{12}{*}{ Stored } & \multirow{6}{*}{ 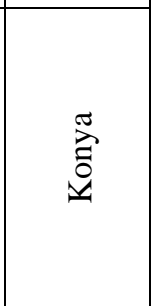 } & DC17 & $30.97 \mathrm{~h}$ & $11.60 \mathrm{~b}$ & $420.81 \mathrm{e}$ & $2,521.90 \mathrm{c}$ & $1,380.05 \mathrm{e}$ & $4,816.92 \mathrm{gh}$ \\
\hline & & DC28 & $27.30 \mathrm{ij}$ & $9.20 \mathrm{f}$ & $27.97 \mathrm{~g}$ & $2,015.24 \mathrm{de}$ & $984.93 \mathrm{~h}$ & $7,951.79 \mathrm{c}$ \\
\hline & & DC33 & $61.68 \mathrm{~b}$ & $11.73 \mathrm{~b}$ & $40.91 \mathrm{~g}$ & $491.42 \mathrm{i}$ & $284.94 \mathrm{n}$ & $6,044.10 \mathrm{f}$ \\
\hline & & DC34 & $57.72 \mathrm{c}$ & $7.03 \mathrm{j}$ & $31.73 \mathrm{~g}$ & $1,479.04 \mathrm{~g}$ & $667.14 \mathrm{k}$ & $4,415.64 \mathrm{~h} 1$ \\
\hline & & DC36 & $43.07 \mathrm{f}$ & $10.13 \mathrm{~d}$ & $1,306.69 \mathrm{~b}$ & $5,300.95 \mathrm{~b}$ & $3,756.25 \mathrm{~d}$ & $9,818.46 \mathrm{a}$ \\
\hline & & DC37 & $64.93 \mathrm{~b}$ & $6.83 \mathrm{k}$ & $26.30 \mathrm{~g}$ & $562.85 \mathrm{i}$ & $412.74 \mathrm{~m}$ & $6,510.77 \mathrm{de}$ \\
\hline & & DC17 & $51.03 \mathrm{~d}$ & $10.23 \mathrm{~d}$ & $251.00 \mathrm{f}$ & $2,263.56 \mathrm{~cd}$ & $1,213.90 \mathrm{f}$ & $4,839.45 \mathrm{gh}$ \\
\hline & & DC28 & $24.87 j$ & 6.351 & $17.13 \mathrm{~g}$ & $1,501.74 \mathrm{~g}$ & $820.37 \mathrm{ij}$ & $6,020.80 \mathrm{f}$ \\
\hline & & DC33 & $69.25 \mathrm{a}^{*}$ & $7.93 \mathrm{~h}$ & $60.99 \mathrm{~g}$ & $538.86 \mathrm{i}$ & $260.56 n$ & $4,659.62 \mathrm{gh}$ \\
\hline & & DC34 & $63.37 \mathrm{~b}$ & $7.48 \mathrm{i}$ & $26.50 \mathrm{~g}$ & $1,673.31 \mathrm{fg}$ & $747.26 \mathrm{j}$ & $6,006.39 \mathrm{f}$ \\
\hline & & DC36 & $57.84 \mathrm{c}$ & $9.64 \mathrm{e}$ & $1,004.87 \mathrm{c}$ & $5,394.27 \mathrm{~b}$ & $4,217.13 \mathrm{c}$ & $9,781.66 \mathrm{a}$ \\
\hline & & DC37 & $55.95 \mathrm{c}$ & $5.13 \mathrm{~m}$ & $32.44 \mathrm{~g}$ & $636.55 \mathrm{i}$ & $452.32 \mathrm{~lm}$ & $6,600.44 \mathrm{de}$ \\
\hline \multirow{12}{*}{$\begin{array}{l}\text { Non- } \\
\text { stored }\end{array}$} & \multirow{6}{*}{ 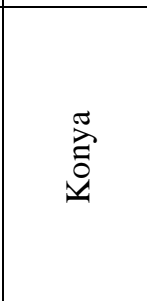 } & DC17 & $11.61 \mathrm{~m}$ & $7.90 \mathrm{~h}$ & $140.97 \mathrm{fg}$ & $600.95 \mathrm{i}$ & $414.42 \mathrm{~m}$ & $6,180.00 \mathrm{ef}$ \\
\hline & & DC28 & $4.94 \mathrm{n}$ & $10.53 \mathrm{c}$ & $20.43 \mathrm{~g}$ & $2,291.43 \mathrm{~cd}$ & $1,109.13 \mathrm{~g}$ & $8,597.95 \mathrm{~b}$ \\
\hline & & DC33 & $19.73 \mathrm{k}$ & $10.20 \mathrm{~d}$ & $11.34 \mathrm{~g}$ & $621.90 \mathrm{i}$ & $310.57 \mathrm{n}$ & $3,404.10 \mathrm{k}$ \\
\hline & & DC34 & $26.89 \mathrm{ij}$ & $8.93 \mathrm{~g}$ & $27.97 \mathrm{~g}$ & $993.33 \mathrm{~h}$ & 512.501 & $3,973.33 \mathrm{j}$ \\
\hline & & DC36 & $42.51 \mathrm{f}$ & $12.36 \mathrm{a}$ & $1,692.43 \mathrm{a}$ & $5,772.38$ a & $4,519.47 \mathrm{~b}$ & $9,733.84 a$ \\
\hline & & DC37 & $37.43 \mathrm{~g}$ & $10.53 \mathrm{c}$ & $37.85 \mathrm{~g}$ & $948.57 \mathrm{~h}$ & $237.26 \mathrm{n}$ & $6,867.18 \mathrm{~d}$ \\
\hline & \multirow{6}{*}{$\begin{array}{l}\stackrel{\tilde{z}}{\partial} \\
\frac{0}{\tilde{J}}\end{array}$} & DC17 & $42.37 \mathrm{f}$ & $8.80 \mathrm{~g}$ & $575.28 \mathrm{~d}$ & $2,005.24 \mathrm{de}$ & $1,047.75 \mathrm{gh}$ & $4,861.79 \mathrm{~g}$ \\
\hline & & DC28 & $3.00 \mathrm{n}$ & $5.10 \mathrm{~m}$ & $55.11 \mathrm{~g}$ & $988.57 \mathrm{~h}$ & $656.73 \mathrm{k}$ & $4,090.00 \mathrm{ij}$ \\
\hline & & DC33 & $29.32 \mathrm{hi}$ & $6.76 \mathrm{k}$ & $12.76 \mathrm{~g}$ & $586.19 \mathrm{i}$ & $235.65 n$ & $3,274.62 \mathrm{k}$ \\
\hline & & DC34 & $55.15 \mathrm{c}$ & $7.96 \mathrm{~h}$ & $35.48 \mathrm{~g}$ & $1,867.62$ ef & 827.08 i & $7,592.82 \mathrm{c}$ \\
\hline & & DC36 & $47.30 \mathrm{e}$ & $10.43 \mathrm{c}$ & $1,123.00 \mathrm{c}$ & $5,486.67 \mathrm{ab}$ & $4,676.92 \mathrm{a}$ & $9,744.10 \mathrm{a}$ \\
\hline & & DC37 & 15.691 & $4.56 \mathrm{n}$ & $28.81 \mathrm{~g}$ & 710.47 hi & 492.071 & $6,690.26 \mathrm{~d}$ \\
\hline
\end{tabular}

* Means within a column that have a different small letter are significantly different from each other $(\mathrm{P}<0.01)$. Lettering was made according to results of variance analyses. Abbrevations as in Table 3 
According to Table 4, AC content of the six purple carrot genotypes ranked between $1,692.43-11.34 \mathrm{mg} \mathrm{l}^{-1}$, obtained from non-stored roots of genotype DC36 and genotype DC33 respectively, grown in Konya location. With respect to the results, AC content of genotype DC36 found higher than the other genotypes in all locations whether stored or not. Leja et al. (2013) compared the contents of carrots in different colours and reported that purple or black carrots contain more AC than the other coloured varieties.

In a study conducted in Spain, researchers found that two commercial varieties (Antonina, Purple haze) have AC 93-126 mg/100 $\mathrm{g}$ in fresh weight respectively (Algarra et al., 2014). In another study, researchers stated that analyses of TP and AC showed significant genotype $\times$ environment interactions also in blueberry cultivars (Connor et al., 2002). Recently, newly developed carrot varieties with an extremely high content of anthocyanin (nearly $1,750.00 \mathrm{mg} / \mathrm{kg}$ in fresh weight) is cultivated in the fields (Mazza and Miniati, 1993).

The difference between the TP contents of genotypes was found statistically significant $(\mathrm{p}<0.01)$. The fresh roots of genotype DC36 cultivated in Konya and Yalova received the highest value $\left(5.772,38-5.486,67 \mathrm{mg} \mathrm{GAE} 100 \mathrm{~g}^{-1}\right)$. In this study, the lowest TP values obtained from stored roots of genotype DC33 harvested from Yalova and Konya (538.86- $491.42 \mathrm{mg}$ GAE $100 \mathrm{~g}^{-1}$ ). When the results considered location and location $\times$ storage interactions were non-significant on TP content. Kramer et al. (2012) reported that total phenolic content varied in a wide range among different coloured carrot roots but purple cultivars significantly exceeded other coloured roots and also influence of growing location was found to be weak in that study. In a trial, 35 carrot accessions, 15 of them orange, 8 yellow, 5 white, 5 red and 2 purple roots were investigated and purple and red ones were determined as rich in phenols (19.8 to $342.2 \mathrm{mg} 100 \mathrm{~g}^{-1}$ in fresh weight). Also researchers stated that, carrots developing purple roots possessed on average 9 times more phenolic than roots of other colours (Leja et al., 2013). Obtained results showed that used genotypes of the current study, have higher TP content than the previous results. In addition to this, in a research on Guava fruit, TP contents of four genotypes were found 170-344 mg $100 \mathrm{~g}^{-1}$ in fresh weight (Thaipong et al., 2006). It can be understood that studied carrot roots have much TP content even from the guava genotypes.

It is evident from the Table 4 that used genotypes were significantly influenced all of the studied parameters. So the genotypes were grown in Konya or Yalova even if they stored or not, when the studied parameters considered, the differences between the used purple carrot genotypes found significant. Like these findings, Nicolle et al. (2004) and Kramer et al. (2012) found significant differences on mineral compound and total phenolic content of the different carrot cultivars used in their study even if they were in same color.

With the current experiment, functional properties of the selected six genotypes were identified, so it is possible to choose the appropriate genotype before start the any study. Such as, it was clear from the experiment, genotype DC36 was found superior to the other genotypes in all applications for all parameters except IS. On the other hand, when the results of genotype DC33 considered, according to AC, TF, TP content and AA values, it was ranked last on the list but its TSS and IS values ranked top compared to the other genotypes.

In the present work used two (Konya, Yalova) locations did not find significant in terms of the total phenolic and flavonoid content of the purple carrot roots (Table 5). However, the other examined parameters like those of AC, AA, TSS and TA were 
affected from the different environmental conditions. When the TSS values were examined, it was determined that the effect of the location was significant and the genotypes DC36, DC33, DC17, DC28 and DC37 from the carrots grown in Konya were higher TSS values than the ones in Yalova. It has been found that genotype DC34 received 8.9 TSS from the fresh roots of Konya and the other DC34 numbered applications were below this value. It is possible to have different TSS contents because of the effects of different climate conditions (Ersus and Yurdagel, 2007). In a study researchers deal with the detect of the AC profile and AA features of two different black carrots cultivars. While material collecting, researchers took into account growing region and they picked roots from the same location of Southern Spain. As could be understood that, the field conditions could be affect the characteristic of the roots (Algarra, 2014).

The contents of TF was significant for interaction of genotype $\times$ storage, and genotype $\times$ location (Table 5). According to this study, although the genotypes differ in their TF content, chill storage for two months did not affect the TF content of carrot roots (Table 5). Moreover, chill storage did not affect the AA according to FRAP values but with respect to DPPH results, storage effect was found statistically important on AA. Alasalvar et al. (2005) studied chill storage effects on AA, AC and TP contents. While total AA remained comparatively constant in orange ones, there was significant decrease was observed in purples. In addition, the content of $\mathrm{AC}$ in purples decreased slightly but TP increased at a much higher rate during storage than orange carrots. In our research the effect of chill storage for two months found statistically important when the other applications considered. Klaiber et al. (2005) reported that the content of TP increased throughout the storage of carrots under aerobic conditions.

Table 5. The effects of location and storage on flavonoid and titratable acid contents of purple carrot genotypes

\begin{tabular}{c|c|c|c|c|c|c|c}
\hline Location & Genotype & TF & TA & Storage & Genotype & TF & TA \\
\hline \multirow{5}{*}{ Konya } & DC17 & $1,208.46 \mathrm{~b}$ & $0.14 \mathrm{e}$ & & DC17 & $1,505.18 \mathrm{c}$ & $0.20 \mathrm{~cd}$ \\
& DC28 & $1,232.38 \mathrm{~b}$ & $0.14 \mathrm{e}$ & & DC28 & $1,046.33 \mathrm{~d}$ & $0.21 \mathrm{c}$ \\
& DC33 & $417.58 \mathrm{f}$ & $0.14 \mathrm{e}$ & \multirow{4}{*}{ Stored } & DC33 & $476.20 \mathrm{gh}$ & $0.18 \mathrm{de}$ \\
& DC34 & $628.16 \mathrm{def}$ & $0.27 \mathrm{~b}$ & & DC34 & $777.72 \mathrm{def}$ & $0.43 \mathrm{a}$ \\
& DC36 & $\mathbf{3 , 1 0 1 . 3 1} \mathbf{a}$ & $0.26 \mathrm{~b}$ & & DC36 & $2,832.26 \mathrm{~b}$ & $0.36 \mathrm{~b}$ \\
& DC37 & $600.64 \mathrm{def}$ & $0.14 \mathrm{e}$ & & DC37 & $489.36 \mathrm{gh}$ & $0.17 \mathrm{ef}$ \\
\hline \multirow{6}{*}{ Yalova } & DC17 & $1,088.80 \mathrm{bc}$ & $0.22 \mathrm{c}$ & & DC17 & $792.08 \mathrm{def}$ & $0.16 \mathrm{gh}$ \\
& DC28 & $803.44 \mathrm{cde}$ & $0.26 \mathrm{~b}$ & & DC28 & $989.49 \mathrm{de}$ & $0.19 \mathrm{de}$ \\
& DC33 & $471.42 \mathrm{f}$ & $0.20 \mathrm{~cd}$ & \multirow{2}{*}{ Non-stored } & DC33 & $412.79 \mathrm{~h}$ & $0.16 \mathrm{gh}$ \\
& DC34 & $878.22 \mathrm{~cd}$ & $0.31 \mathrm{a}$ & & DC34 & $728.67 \mathrm{efg}$ & $0.14 \mathrm{~h}$ \\
& DC36 & $\mathbf{2 , 9 7 3 . 4 5} \mathbf{a}$ & $0.30 \mathrm{a}$ & & DC36 & $\mathbf{3 , 2 4 2 . 4 9} \mathbf{a}$ & $\mathbf{0 . 2 0} \mathbf{c d}$ \\
& DC37 & $520.46 \mathrm{ef}$ & $0.19 \mathrm{~d}$ & & DC37 & $631.75 \mathrm{fgh}$ & $0.15 \mathrm{fg}$ \\
\hline
\end{tabular}

*Means within a column that have a different small letter are significantly different from each other $(\mathrm{P}<0.01)$. Lettering was made according to results of variance analyses

\section{Conclusion}

Because of its nutritional features, purple carrot is a valuable product and it is exported to the many countries around the world from Turkey. With this study, the 
effects of different environmental conditions and storage on the characteristics of the purple carrot roots were determined. The studies were carried out under natural environmental conditions. It has been understood that the used purple carrot genotypes could be grown outside the current cultivation area. However, with the effect of ecological conditions, the differences in both quality characteristics and external appearance of the roots have been detected. It was observed that the roots harvested from Yalova unsuitable for the fresh market. Moreover, the effect of storage on all applications except total flavonoid content was found significant. These results should be taken into consideration by the producers, plant breeders and processing industry members. In future studies, detailed physiological analysis under fully controlled conditions (such as growth chamber) can be great benefit to plant breeders and food scientists. Furthermore, associations between dietary patterns and gene expression profiles of healthy men and women and additionally investigating the relationship between nutritional values and gene expression profiles of genotypes can be great benefit to plant breeders. With the further studies, the production and consumption of purple carrot, a beneficial, highly nutritional and inexpensive food, can be expanded.

Acknowledgements. The authors would like to thank to Dr. S. Secil Erdogan for the technical advices in laboratory studies and Necati Simsekli for the field experiments in Konya location. This study supported by the General Directorate of Agricultural Research and Policies of Ministry of Agriculture and Forestry of Turkey Republic between the years of 2013-2017.

\section{REFERENCES}

[1] Alasalvar, C. J., Grigor, M., Zhang, D., Quantick, P. C. Shahidi, F. (2001): Comparison of volatiles, phenolics, sugars, antioxidant vitamins, and sensory quality of different coloured carrot varieties. - Journal of Agriculture and Food Chemistry 49: 1410-1416. https://doi.org/10.1016/j.foodchem.2005.07.042.

[2] Alasalvar, C. J., Al-Farsi, M., Quantick, P. C., Shahidi, F., Wiktorowicz, R. (2005): Effect of chill storage and modified atmosphere packaging (MAP) on antioxidant activity, anthocyanins, carotenoids, phenolics and sensory quality of ready to eat shredded orange and purple carrots. $\quad-\quad$ Food Chemistry 89(1): 69-76. https://doi.org/10.1016/j.foodchem.2004.02.013.

[3] Algarra, M., Fernandes, A., Mateus, N., Freitas, V., Esteves da Silva, J. C. G., Casado, J. (2014): Anthocyanin profile and antioxidant capacity of black carrots from Cuevas Bajas, Spain. - Journal of Food Composition Analysis 33: 71-76. https://doi.org/10.1016/j.jfca.2013.11.005.

[4] Anonymous (2018): Turkish State Meteorological Service. https://mgm.gov.tr/eng/forecast-cities.aspx.

[5] Arscott, S. A., Tanumihardjo, S. A. (2010): Carrots of many colors provide basic nutrition and bioavailable phytochemicals acting as a functional food. - Comprehensive Reviews in Food Science and Food Safety (9): 223-239. https://doi.org/10.1111/j.15414337.2009.00103.x.

[6] Benzie, I. F., Strain, J. J. (1996): The FRAP as a measure of "antioxidant power": the FRAP assay. - $\quad$ Analytical Biochemistry 239: 70-76. https://doi.org/10.1006/abio.1996.0292.

[7] Cemeroglu, B. (2007): Food analysis. - Food Technology Association Publication 34: 7075.

[8] Connor, A. M., Luby, J. J., Tong, C. B. S., Finn, C. E., Hancock, J. F. (2002): Genotyping and environmental variation in antioxidant activity, total phenolic content, anthocyanin 
content among blueberry cultivars. - Journal of American Society for Horticultural Science 127(1): 89-97.

[9] Ersus, S., Yurdagel, U. (2007): Microencapsulation of anthocyanin pigments of black carrot by spray drier. - Journal of Food Engineering 80: 805-812. https://doi.org/10.1016/j.jfoodeng.2006.07.009.

[10] Esatbeyoglu, T., Rodríguez-Werner, M., Schlösser Liehr, A. M., Ipharraguerre, I., Winterhalter, P., Rimbach, G. (2016): Fractionation of plant bioactives from black carrots by adsorptive membrane chromatography and analysis of their potential anti-diabetic activity. - Journal of Agriculture and Food Chemistry 64: 5901-5908. DOI: 10.1021/acs. jafc.6b02292.

[11] Ipek, A., Turkmen, O., Fidan, S., Ipek, M., Karc1, H. (2016): Genetic variation within the purple carrot population grown in Ereğli District in Turkey. - Turkish Journal of Agriculture and Forestry 40: 570-576. DOI: 10.3906/tar-1512-90.

[12] Kirca, A., Özkan, M., Cemeroglu, B. (2006): Stability of black carrot anthocyanins in various fruit juices and nectars. - Food Chemistry 97: 598-605. https://doi.org/10.1016/j.foodchem.2005.05.036.

[13] Klaiber, R. G., Baur, S., Koblo, A., Carle, R. (2005): Influence of washing treatment and storage atmosphere on phenyl alanine ammonialyase activity and phenolic acid content of minimally processed carrot sticks. - Journal of Agriculture and Food Chemistry 53: 1065-1072. DOI: 10.1021/jf049084b.

[14] Kramer, M., Maksylewicz-Kau, A., Baranski, R., Nothnagel, T., Carle, R., Kammerer, D. R. (2013): Effects of cultivation year and growing location on the phenolic profile of differently coloured carrot cultivars. - Journal of Applied Botany and Food Quality 85(2): 235.

[15] Leja, M., Kamińska, I., Kramer, M., Maksylewicz-Kaul, A., Kammerer, D., Carle, R., Baranski, R. (2013): The content of phenolic compounds and radical scavenging activity varies with carrot origin and root color. - Plant Food and Human Nutrition 68: 163-170. doi.org/10.1007/s11130-013-0351-3.

[16] Mazza, G., Miniati, E. (1993): Anthocyanins in fruits, vegetables, and grains. - CRC Press, Boca Raton, FL.

[17] Moyer, R. A., Hummer, K. E., Fınn, C. E., Frei, B., Wrolstad, R. E. (2002): Anthocyanins, phenolics, and antioxidant capacity in diverse small fruits: vaccinium, rubus, and ribes. - Journal of Agriculture and Food Chemistry 50: 519-525. DOI: $10.1021 / \mathrm{jf011062r}$.

[18] Nicolle, C., Simon, G., Rock, E., Amoroux, P., Remesy, C. (2004): Genetic variability influences carotenoid, vitamin, phenolic and mineral content in white, yellow, purple, orange, dark orange carrot cultivars. - Journal of American Society for Horticultural Science 129(4): 523-529.

[19] Seljasen, R., Kristensen, H. L., Lauridsen, C., Wyss, G. S., Kretzschmar, U., Birlouez-Aragone, I., Kahl, J. (2013): Quality of carrots as affected by pre-and postharvest factors and processing. - Journal of the Science of Food and Agriculture 93(11): 2611-2626.

[20] Sharma, K. D., Karki, S., Thakur, N. S., Attri, S. (2012): Chemical composition, functional properties and processing of carrot. A review. - Journal of Food Science and Technology 49: 22. https://doi.org/10.1007/s13197-011-0310-7.

[21] Simon, P. W., Freeman, R. E., Vieira, J. V., Boiteux, L. S., Briard, M., Nothnagel, T., Michalik, B., Kwon, Y. S. (2008): Carrot. - In: Prohens, J., Nuez, F. (eds.) Vegetables II. Handbook of Plant Breeding. Vol. 2. Springer, New York, pp: 327-357.

[22] Smeriglio, A., Denaro, M., Barreca, D., D’Angelo, V., Germanò, M. P., Trombetta, D. (2018): Polyphenolic profile and biological activities of black carrot crude extract. Fitoterapia 124: 49-57. https://doi.org/10.1016/j.fitote.2017.10.006.

[23] Singh, D. P., Beloy, J., Mclnerney, J. K., Day, L. (2011): Impact of boron, calcium and genetic factors on vitamin $\mathrm{C}$, carotenoids, phenolic acids, anthocyanins and antioxidant 


$$
-15254-
$$

capacity of carrots. $\quad-$ Food Chemistry 132: 1161-1170. https://doi.org/10.1016/j.foodchem.2011.11.045.

[24] Sun, T., Simon, P. W., Tanumihardjo, S. A. (2009): Antioxidant phytochemicals and antioxidant capacity of biofortified carrots (Daucus carota L.) of various colors. - Journal of Agricultural and Food Chemistry 57(10): 4142-4147.

[25] Thaipong, K., Unaroj, B., Crosbyb, K., Cisneros-Zevallosc, L., Byrne, D. H. (2006): Comparison of ABTS, DPPH, FRAP, and ORAC assays for estimating antioxidant activity from guava fruit extracts. - Journal of Food Composition Analysis 19: 669-675. https://doi.org/10.1016/j.jfca.2006.01.003.

[26] Zhishen, J., Mengcheng, T., Jianming, W. (1999): The determination of flavonoid contents in mulberry and their scavenging effects on superoxide radicals. - Food Chemistry 64(4): 555-559. 